DOI: $10.17951 / 1 r p .2017 .36 .1 .207$

\author{
EMILIA CAŁCZYŃsKa
}

Uniwersytet Marii Curie-Skłodowskiej w Lublinie

\title{
POSTRZEGANIE SIEBIE PRZEZ JEDYNAKÓW I DZIECI MAJĄCE RODZEŃSTWO
}

\author{
Nie zabraniajmy dziecku rysować. \\ Niech wypowiada się właśnie w ten sposób \\ i pamiętajmy, że jest to jego mowa, \\ nie werbalna, lecz graficzna - ale mowa.
}

Anna Kalbarczyk (2007)

\begin{abstract}
Abstrakt: Artykuł przedstawia wyniki badań własnych poświęconych problematyce obrazu siebie w rysunkach jedynaków i dzieci mających rodzeństwo. Podjęte badania dostarczają istotnych informacji na temat osobowości dzieci, ich samooceny, poczucia własnej wartości oraz twórczości plastycznej we wczesnej edukacji. Pozwalają również odpowiedzieć na pytanie dotyczące różnic w postrzeganiu siebie między jedynakami a niejedynakami.
\end{abstract}

Słowa kluczowe: obraz siebie, samoocena, poczucie własnej wartości, jedynak, rysunek projekcyjny

\section{WPROWADZENIE}

Na gruncie psychologii pojęcie samego siebie określa się jako system poglądów, wiedzy i przeświadczeń jednostki o własnych fizycznych cechach, możliwościach, predyspozycjach i umiejętnościach. Jest to zbiór wyobrażeń o własnym wyglądzie zewnętrznym oraz stosunkach z innymi ludźmi. Wykreowany obraz siebie ma stanowić odpowiedź na pytanie: „Kim jestem?” (Schaffer 2005, s. 336; Brzezińska 1973, s. 88; Kulas 1986, s. 16). Stanowi komponent samooceny i poczucia własnej wartości. Zarówno postrzeganie siebie, jak i samoocena formułuje się dość intensywnie w okresie wczesnodziecięcym. Samoocena dzieci w wieku przedszkolnym 
i wczesnoszkolnym kształtuje się na bazie doświadczeń środowiskowych, przede wszystkim podczas kontaktów z rodzicami, rówieśnikami oraz innymi osobami znaczącymi dla dziecka.

Samoocena jest próbą odpowiedzi na pytanie: „Jak dobry jestem?”. Jej obszar rozciąga się od bardzo prawdopodobnej do bardzo negatywnej (Schaffer 2005, s. 336). Obydwie skrajności niekorzystnie oddziaływają na rozwój psychospołeczny młodego człowieka. Zawyżona samoocena powoduje, że dzieci oczekują częstego chwalenia i wyróżniania od osób dorosłych, natomiast niska wywołuje wycofanie, nieśmiałość, niepewność i lęk przed nowymi sytuacjami (Knedler 2011, s. 29).

Budowanie prawidłowej samooceny u dzieci stanowi dla rodziców ważne zadanie, które powinno być spełniane poprzez stosowanie właściwych postaw i stylów wychowania. Warto zauważyć, że w rodzinach z jednym dzieckiem mogą pojawić się problemy wychowawcze. Jedynak, jako najmłodszy członek rodziny, jest zazwyczaj obdarzany gorliwą miłością i skupia na sobie całą uwagę rodzicielską. Nadopiekuńczość i znaczne zainteresowanie dzieckiem mogą przyczynić się do powstania wysokiej samooceny, która prowadzi do egoizmu (Turowska 1987, s. 69). Zdaniem Haliny Filipczuk przesadna troska wpływa na to, iż jedynak „zawsze i wszędzie musi być na pierwszym planie, w centrum uwagi wszystkich. Traktowany [...] na równi z innymi, bez nadmiaru zainteresowania i serdeczności, czuje się nieszczęśliwy i pokrzywdzony" (Filipczuk 1987, s. 83). Podobne stanowisko wyraża Stanisław Gerstmann, stwierdzając, iż „wychowanie takie prowadzi do braku równowagi emocjonalnej tych dzieci oraz nadmiaru oczekiwań i żądań od otoczenia” (za: Turowska 1987, s. 69).

Jednak powstało wiele publikacji (m.in. Tyszkowa 1985, Kumpel 2007) wskazujących na to, że jedynacy nie różnią się od osób mających rodzeństwo. Margarete Kumpel (2007) twierdzi, że „wzrastanie bez rodzeństwa nie jest ujmą, tak jak nie jest nią wzrastanie w towarzystwie rodzeństwa. Bowiem dla rozwoju dziecka decydujące są inne czynniki, wśród których szczególne znaczenie ma styl wychowania".

Na obraz własnej osoby mogą oddziaływać różne elementy społeczno-kulturowe. To jak, dziecko widzi siebie, zależy od jego wieku, struktury i sytuacji rodzinnej, postaw rodzicielskich i stylów wychowania oraz jego kontaktów interpersonalnych z innymi ważnymi osobami. Badanie „obrazu siebie” we wczesnej edukacji jest istotne z punktu widzenia pedagogicznego, gdyż ukształtowana w dzieciństwie samoocena zostaje z człowiekiem na całe życie i rzutuje na jego późniejsze decyzje, plany życiowe i stosunki interpersonalne. W świetle powyższych rozważań zasadne wydaje się podjęcie takich badań, które pozwolą poznać obraz siebie dzieci mających rodzeństwo i jedynaków w wieku wczesnoszkolnym. 


\section{PROBLEMY BADAWCZE}

Główny problem badawczy ujęto w pytaniu: „Jaki obraz własnej osoby jedynaków i dzieci mających rodzeństwo rysuje się w ich wytworach plastycznych?”. Natomiast szczegółowe problemy badawcze przedstawiono następująco:

- Jaki jest obraz własnej osoby w świetle warstwy przedstawieniowej rysunków jedynaków i dzieci mających rodzeństwo?

- Jakie różnice w obrazie własnej osoby jedynaków i dzieci mających rodzeństwo zaznaczają się w świetle ich wytworów plastycznych?

- W jakim zakresie rysunki jedynaków i dzieci mających rodzeństwo ujawniają wskaźniki niepokoju i agresji?

\section{METODA BADAŃ}

Badania przeprowadzono przy wykorzystaniu metody projekcyjnej - testu rysunku człowieka. W tym przypadku dzieci miały za zadanie narysowanie siebie. Wybierając tę metodę, sugerowano się tym, iż najmłodszym czasem trudno jest wyrazić werbalnie to, co czują i przeżywają. Mogą to jednak przekazać za pomocą wytworów plastycznych. Rysunek postaci ludzkiej jest kopalnią wiedzy, pełną symboli i ukrytych znaczeń na temat osobowości młodego człowieka, takich jak koncepcja „ja”, samoocena oraz sposób postrzegania przez dziecko własnego ciała i przystosowania do otaczającego środowiska (Rodriguez 2013, s. 59). Rysunek dostarcza bardzo cennych informacji dotyczących aktualnego stanu emocjonalnego autora, bowiem według Stanisława Popka dzięki twórczości plastycznej dziecko przekazuje istniejącą rzeczywistość poprzez swoje „wewnętrzne potrzeby, pragnienia, zainteresowania, aspiracje, silnie zabarwione uczuciowo, ujawniają cechy temperamentalno-charakterologiczne, a także zdolnościowe” (Popek 1978, s. 83). Można by sądzić, że gotowe dzieła plastyczne są identyfikatorami osoby autora.

\section{GRUPA BADAWCZA}

Badania zostały przeprowadzone w maju 2015 roku. Wybrano dwie publiczne szkoły podstawowe w największych miastach województwa mazowieckiego - w Warszawie i Radomiu. Są to szkoły z wieloletnią tradycją, zlokalizowane blisko terenu osiedlowego, w których uczy się średnio 500 dzieci.

Grupy do badań zostały wybrane na zasadach doboru celowego. Kierowano się przedziałem wiekowym (6-7 lat) oraz tym, czy dzieci mają rodzeństwo, czy nie 
mają. Wiek badanych i strukturę rodziny ustalono na podstawie dokumentacji klasowej (dzienników lekcyjnych) oraz rozmów prowadzonych z nauczycielami. Grupę podstawową tworzyło 30 jedynaków (14 dziewcząt i 16 chłopców). Natomiast grupa porównawcza (13 dziewcząt i 17 chłopców) została zebrana w taki sposób, aby obydwie grupy badawcze (jedynaków i niejedynaków) miały po tyle samo osób. Dodatkowo starano się, aby w obu grupach liczebność dziewczynek i chłopców była zbliżona.

Tabela 1. Struktura badanej grupy z uwzględnieniem płci i występowania rodzeństwa

\begin{tabular}{|c|c|c|c|c|c|c|}
\hline \multirow{2}{*}{ Płeć dziecka } & \multicolumn{2}{|c|}{$\begin{array}{c}\text { Jedynacy } \\
\mathrm{N}=30\end{array}$} & \multicolumn{2}{|c|}{$\begin{array}{c}\text { Niejedynacy } \\
\mathrm{N}=30\end{array}$} & \multicolumn{2}{|c|}{$\begin{array}{l}\text { Razem } \\
\mathrm{N}=60\end{array}$} \\
\hline & $\mathrm{L}$ & $\%$ & $\mathrm{~L}$ & $\%$ & $\mathrm{~L}$ & $\%$ \\
\hline Dziewczynki & 14 & 47 & 13 & 43 & 27 & 45 \\
\hline Chłopcy & 16 & 53 & 17 & 57 & 33 & 55 \\
\hline
\end{tabular}

Źródło: opracowanie własne.

Jak wynika $\mathrm{z}$ danych przedstawionych w tabeli 2 , znaczna część badanych dzieci wychowuje się w rodzinach pełnych. Ośmioro jedynaków pochodzi z rodziny niepełnej (rodzice są po rozwodzie). Do tej grupy należy też czworo dzieci mających rodzeństwo. $Z$ wywiadu przeprowadzonego wśród nauczycieli wynika, że nad tymi dziećmi sprawują opiekę samotne matki lub oboje rodziców (dzieci mają dwa domy).

Tabela 2. Osoby badane - podział ze względu na strukturę rodziny

\begin{tabular}{|l|r|c|c|c|}
\hline \multirow{2}{*}{\begin{tabular}{l}
\multirow{2}{*}{ Struktura rodziny } \\
\cline { 2 - 5 }
\end{tabular}} & \multicolumn{2}{|c|}{ Jedynacy } & \multicolumn{2}{c|}{ Niejedynacy } \\
\cline { 2 - 5 } & $\mathrm{N}=30$ & $\%$ & $\mathrm{~L}$ & $\%$ \\
\hline Pełna & 22 & 73 & 26 & 87 \\
\hline Niepełna & 8 & 27 & 4 & 13 \\
\hline
\end{tabular}

Źródło: opracowanie własne.

\section{WYNIKI BADAŃ}

Rysunki dzieci analizowano na podstawie warstwowej struktury wytworu plastycznego w ujęciu Popka (2001, s. 122-121). Brano pod uwagę warstwę I (treść przedstawieniową - warstwę semantyczną) i warstwę II (treść formalną). Na podstawie warstwy semantycznej można udzielić odpowiedzi na pytania: (1) „Co przedstawia, co obrazuje, jakie treści poznawcze wyraża dzieło?”, (2) „Jaki jest poziom konkretyzacji/abstrakcyjności obrazowanych treści?”. Natomiast warstwa formalna dotyczy 
poziomu graficznego rysunku, siły dynamiki nacisku, kolorystyki, kompozycji. Pozwala odpowiedzieć na pytanie: „Jak przedstawione są dziecięce wizje, za pomocą jakich środków wyrazu plastycznego, za pomocą jakiego alfabetu?”. Uzyskane wyniki zostały zawarte w tabelach 3-13. Dodatkowo ocena wykonania rysunku pozwoliła stwierdzić, w jakim stadium rozwoju twórczości plastycznej znajdują się badane dzieci (tabela 3).

Tabela 3. Poziom wykonania rysunku w odniesieniu do wieku dziecka

\begin{tabular}{|c|c|c|c|c|}
\hline \multirow[t]{2}{*}{ Poziom wykonania } & \multicolumn{2}{|c|}{$\begin{array}{c}\text { Jedynacy } \\
\mathrm{N}=30\end{array}$} & \multicolumn{2}{|c|}{$\begin{array}{c}\text { Niejedynacy } \\
\mathrm{N}=30\end{array}$} \\
\hline & $\mathrm{L}$ & $\%$ & $\mathrm{~L}$ & $\%$ \\
\hline Adekwatny do wieku życia & 11 & 37 & 8 & 27 \\
\hline Poniżej wieku życia & 16 & 53 & 22 & 73 \\
\hline Powyżej wieku życia & 3 & 10 & 0 & 0 \\
\hline
\end{tabular}

Źródło: opracowanie własne.

Jak wskazują dane zawarte w tabeli, najwięcej badanych jedynaków i niejedynaków wykonało prace plastyczne na poziomie poniżej własnego wieku życia. Rysunki zgodne $\mathrm{z}$ normami dla danego etapu rozwojowego dominowały w grupie jedynaków (zauważono 37\% takich prac, natomiast u dzieci z rodzin większych - 27\%). Rysunków na poziomie wyższym niż wskazywałby wiek, było niewiele, i tylko w grupie jedynaków.

Należy zaznaczyć, że badane dzieci znajdowały się w stadium przedschematycznym (4.-7. rok życia). Dzieci rozpoczynające naukę w szkolę są w fazie pierwszych prób przedstawiania siebie (Lovenfeld, Brittan 1977, s. 86). W tym okresie pojawia się najwięcej rysunków; są one najciekawsze oraz bogato zagospodarowane (tło wielobarwne, przyozdobione różnymi wzorkami; postacie ludzkie ubrane w bardzo kolorowe stroje i z makijażem na twarzach, ukazane z przodu $\mathrm{z}$ boku; perspektywa rzędowa). Dziecko o prawidłowym rozwoju i zaspokojonych potrzebach psychofizycznych przelewa na papier swoją radość i pogodę ducha (Kalbarczyk 2007, s. 73-75).

Dzieła plastyczne kilkulatków mają charakter subiektywnej interpretacji rzeczywistości, a więc sposób przedstawienia i ocena siebie na rysunku wynika wyłącznie z własnego punku widzenia, a nie obiektywnego odwzorowywania. W okresie wczesnej edukacji rysunki dzieci są bogatsze treściowo, gdyż zaczynają się pojawiać dokładniejsze proporcje. Widać większe przywiązanie do szczegółów i dbałość o przedstawienie jak największej ilości cech charakterystycznych dla rysowanej postaci (Majkut 2014/2015, s. 24). 
Na pierwszym etapie interpretacji dziecięcych prac analizie poddano sposób przedstawienia siebie na rysunku. Informacje na ten temat prezentuje tabela 4 .

Tabela 4. Sposób przedstawienia dziecka na rysunku

\begin{tabular}{|c|c|c|c|c|}
\hline \multirow[t]{2}{*}{ Sposób przedstawienia } & \multicolumn{2}{|c|}{$\begin{array}{c}\text { Jedynacy } \\
\mathrm{N}=30\end{array}$} & \multicolumn{2}{|c|}{$\begin{array}{c}\text { Niejedynacy } \\
\mathrm{N}=30\end{array}$} \\
\hline & $\mathrm{L}$ & $\%$ & $\mathrm{~L}$ & $\%$ \\
\hline Realny wizerunek siebie & 25 & 83 & 30 & 100 \\
\hline Jako bohater z książki lub gry komputerowej & 3 & 10 & 0 & 0 \\
\hline Ujęcie siebie wraz z rówieśnikami & 2 & 7 & 0 & 0 \\
\hline
\end{tabular}

Źródło: opracowanie własne.

Wszystkie dzieci mające rodzeństwo przedstawiły siebie jako realną postać. Świadczy to o rzeczywistej identyfikacji z samym sobą. Natomiast w grupie jedynaków co dziesiąte dziecko narysowało siebie w roli bohatera książkowego bądź z gry komputerowej, co może wskazywać na silny stosunek emocjonalny do tych postaci i na przejmowanie ich wzorców zachowań. Warto zaznaczyć, że we wczesnym dzieciństwie dużą rolę odgrywają fikcyjni bohaterowie z książek, filmów animowanych, czy gier komputerowych. Są oni przytulanką, która wprowadza dziecko w świat marzeń pełen przygód i fantazji (Adamczykowa 2008, s. 33). Na szczególną uwagę zasługuje praca jedynaczki, która narysowała Kopciuszka. Postać ta została upiększona eleganckim strojem oraz wyrazistym makijażem. Taka forma ukazania siebie może wskazywać na zawyżoną samoocenę lub dążenie do perfekcyjnego wyglądu.

Zdarza się, że dzieci wychowujące się bez rodzeństwa są osamotnione i pragną częstszych kontaktów z rówieśnikami. W badanej grupie dwóch jedynaków przedstawiło siebie wśród koleżanek i kolegów. Ten typ rysunku można interpretować dwojako. Po pierwsze, jako projekcję własnych marzeń - wyrażenie chęci nawiązania kontaktów; po drugie, jako ukazanie swojej akceptacji w grupie rówieśniczej.

Ważnym elementem w rysunku postaci ludzkiej jest głowa. Sposób jej przedstawienia dostarcza istotnych informacji dotyczących typu osobowości dziecka, pokazuje, czy jest ono introwertykiem, czy ekstrawertykiem, poza tym określa umiejętności społeczne oraz poziom samokontroli. Za pomocą rysunku głowy młody człowiek wyraża swoje świadome i kontrolowane „ja” (Rodriguez 2013, s. 116). Większość autorów prac narysowało głowę o proporcjonalnych wymiarach, natomiast dziewięciu respondentów - o nienaturalnie dużych. Powiększona głowa może być oznaką społecznej akceptacji, wyjątkowej kreatywności i wybujałej wyobraźni i - zgodnie ze spostrzeżeniami Nory Rodriguez - „sygnałem dużego znaczenia, jakie w otoczeniu dziecka mają aspekty intelektualne" (Rodriguez 2011, s. 116). Mała zaś głowa może wskazywać na nieśmiałość, skłonności 
do wycofywania się oraz deprecjonowanie własnej osoby (Chermet-Carroy 1999, s. 48). Wśród jedynaków znalazło się siedmioro, którzy oddali prace przedstawiające postacie z małą głową.

Kolejnym ważnym elementem rysunku jest twarz, ukazująca obraz własnego „ja” i ściśle powiązana z interakcjami społecznymi jednostki. Twarz stanowi odbicie uczuć, emocji, przeżyć oraz kontaktów interpersonalnych (Goffman 2006, s. 6). W badanej grupie jedynaków zdecydowana większość dzieci (93\%) przedstawiła siebie z pogodnym wyrazem twarzy, co świadczy o przyjazności, radości, otwartości dzieci na kontakty z innymi. Zaledwie dwoje badanych ukazało swoją twarz z wrogą, groźną miną, co prawdopodobnie oznacza gromadzenie w sobie negatywnych uczuć i agresji.

Inaczej przedstawia się sytuacja w grupie porównawczej. Większość autorów rysunków narysowało siebie z radosną miną (73\%), natomiast $20 \%$ z wyrazem twarzy, który został oceniony jako nieprzyjazny i wzbudzający lęk. Pozostałe prace (7\%) wskazywały na przygnębienie i smutek autorów. Ponad połowa niejedynaków narysowała swoją głowę o proporcjonalnych wymiarach. Dwie osoby zaprezentowały wyjątkowo dużą głowę, a cztery małą. Warto zaznaczyć, że w tej grupie znalazły się dwie dziewczynki, które narysowały tylko głowę. Może to wskazywać na chęć ukrycia trudności w relacjach z członkami rodziny bądź na problemy w nawiązywaniu kontaktów z rówieśnikami (Rodriguez 2011, s. 116). Dane, o których mowa, zawiera tabela 5 .

Tabela 5. Przedstawienie swojego wyglądu - głowa i twarz

\begin{tabular}{|c|c|c|c|c|c|}
\hline \multirow[t]{2}{*}{ Sposób przedstawienia } & \multirow[t]{2}{*}{ Cechy } & \multicolumn{2}{|c|}{$\begin{array}{c}\text { Jedynacy } \\
\mathrm{N}=30\end{array}$} & \multicolumn{2}{|c|}{$\begin{array}{c}\text { Niejedynacy } \\
\mathrm{N}=30\end{array}$} \\
\hline & & $\mathrm{L}$ & $\%$ & $\mathrm{~L}$ & $\%$ \\
\hline \multirow{3}{*}{ Głowa } & Duża & 9 & 30 & 2 & 7 \\
\hline & Proporcjonalna & 14 & 47 & 24 & 80 \\
\hline & Mała & 7 & 23 & 4 & 13 \\
\hline \multirow{3}{*}{ Twarz } & Wesoła & 28 & 93 & 22 & 73 \\
\hline & Smutna & 0 & 0 & 2 & 7 \\
\hline & Wroga & 2 & 7 & 6 & 20 \\
\hline
\end{tabular}

Źródło: opracowanie własne.

Kolejna kategoria wykorzystywana w analizie rysunków pozwala opisać spostrzeganie siebie na podstawie sposobu przedstawienia kończyn (tabela 6).

Kończyny przedstawione na rysunku, podobnie jak głowa, dostarczają bardzo cennych informacji na temat komunikacji z innymi osobami oraz usytuowania siebie w otaczającym świecie. W większości jedynacy i niejedynacy narysowali swoje ręce gotowe do kontaktu. Na niektórych rysunkach pojawiły się kończyny 
długie, wyciągnięte wzdłuż tułowia, co prawdopodobnie ma związek z zachowaniami agresywnymi (Rodriguez 2013, s. 123). Rysunków z rękoma przylegającymi do ciała, wskazującymi na brak kontaktu, było niewiele - 13\% u jedynaków i $17 \%$ u niejedynaków. Tego typu prace mogą świadczyć również o skrytości czy zawstydzeniu dzieci. Ponad połowa badanych jedynaków $(60 \%)$ i dzieci z rodzin większych (70\%) postrzega siebie jako osoby mało stabilnie, niemające równowagi wewnętrznej. Świadczy o tym sposób przedstawienia na rysunku nóg. Niektóre dzieci zaprezentowały ujęcie portretowe, w ogóle nie ukazały dolnych kończyn.

Tabela 6. Przedstawienie swojego wyglądu - ręce i nogi

\begin{tabular}{|l|l|c|r|r|r|}
\hline \multirow{3}{*}{ Sposób przedstawienia } & \multirow{2}{*}{ Cechy } & \multicolumn{2}{c|}{$\begin{array}{c}\text { Jedynacy } \\
\mathrm{N}=30\end{array}$} & \multicolumn{2}{c|}{ Niejedynacy } \\
\cline { 2 - 6 } & & $\mathrm{L}$ & $\%$ & $\mathrm{~L}$ & $\%$ \\
\hline \multirow{3}{*}{ Ręce } & Gotowe do kontaktu & 26 & 87 & 25 & 76 \\
\cline { 2 - 6 } & Brak kontaktu & 4 & 13 & 5 & 17 \\
\hline \multirow{3}{*}{ Nogi } & Stabilne & 3 & 10 & 2 & 7 \\
\cline { 2 - 6 } & Mało stabilne & 18 & 60 & 21 & 70 \\
\cline { 2 - 6 } & Brak & 9 & 30 & 7 & 23 \\
\hline
\end{tabular}

Źródło: opracowanie własne.

Wśród jedynaków postać dużą narysowało sześć osób, a małą dwanaście. Postać pomniejszona świadczy o introwertyzmie, nieprzystawaniu społecznym, braku poczucia bezpieczeństwa, wycofaniu, nieśmiałości, poczuciu lęku, natomiast postać bardzo duża może wskazywać na ekspansywność, słabą kontrolę wewnętrzną i wysoką samoocenę (Oster, Gould 2004, s. 36). Z kolei w grupie niejedynaków pięcioro dzieci narysowało powiększoną postać, a dziewięcioro małą (tabela 7).

Tabela 7. Wielkość narysowanej postaci

\begin{tabular}{|l|r|r|r|r|}
\hline \multirow{2}{*}{ Wielkość postaci } & \multicolumn{2}{|c|}{ Jedynacy } & \multicolumn{2}{c|}{ Niejedynacy } \\
& \multicolumn{2}{|c|}{$\mathrm{N}=30$} & $\mathrm{~L}$ & $\%$ \\
\cline { 2 - 5 } & $\mathrm{L}$ & $\%$ & 5 & 17 \\
\hline Duża & 6 & 20 & 16 & 53 \\
\hline Średnia - adekwatna & 12 & 40 & 9 & 30 \\
\hline Mała & 12 & 40 & 50 \\
\hline
\end{tabular}

Źródło: opracowanie własne.

Następnym istotnym czynnikiem w formalnej analizie rysunków jest rozmieszczenie postaci na papierze, bowiem każda część kartki ma inny wymiar symboliczny. Według Sylvie Chermet-Carroy dzieci wypełniają , przestrzeń kartki w taki sam 
sposób, w jaki zajmują przestrzeń, która nas otacza” (Chermet-Carroy 1999, s. 30). Kartkę można podzielić symbolicznie na cztery części: lewą (przeszłość, introwersja, matka), prawą (przyszłość, ekstrawersja, ojciec), górna (stany duchowe), dolna (materia) (Chermet-Carroy 1999, s. 32).

Tabela 8. Rozmieszczenie postaci na kartce

\begin{tabular}{|c|c|c|c|c|}
\hline \multirow{2}{*}{ Rozmieszczenie na rysunku } & \multicolumn{2}{|c|}{$\begin{array}{c}\text { Jedynacy } \\
\mathrm{N}=30\end{array}$} & \multicolumn{2}{|c|}{$\begin{array}{c}\text { Niejedynacy } \\
\mathrm{N}=30\end{array}$} \\
\hline & $\mathrm{L}$ & $\%$ & $\mathrm{~L}$ & $\%$ \\
\hline Centrum & 13 & 43 & 24 & 80 \\
\hline Góra, powyżej środka & 5 & 17 & 2 & 7 \\
\hline Dół, poniżej środka & 0 & 0 & 1 & 3 \\
\hline Prawy brzeg kartki & 4 & 13 & 3 & 10 \\
\hline Lewy brzeg kartki & 8 & 27 & 0 & 0 \\
\hline
\end{tabular}

Źródło: opracowanie własne.

Większość dzieci mających rodzeństwo (80\%) umieściła siebie w centrum kartki. Świadczy to o poczuciu bezpieczeństwa i prawidłowych zdolnościach adaptacyjnych.

Inaczej wygląda sytuacja w grupie jedynaków, bowiem mniej niż połowa respondentów (43\%) narysowała swoją podobiznę w pozycji centralnej. Pięć osób zlokalizowało rysunek w górnej części kartki. Skupienie elementów w tym miejscu oznacza świat marzeń, wyobraźni, duchowości, chęć odkrywania nowych rzeczy, skłonności do fantazjowania oraz pragnienie kontaktów ze światem zewnętrznym. Dziecko, które tworzy wiele takich rysunków, może być typem marzyciela bądź idealisty (Chermet-Carroy 1999, s. 3; Rodriguez 2011, s. 47). Zauważmy, że w kategorii „prawy brzeg kartki” znalazły swoje miejsce zarówno prace jedynaków (13\%), jak i niejedynaków (10\%). Natomiast znacznie więcej jedynaków niż dzieci mających rodzeństwo nagromadziło elementy w pobliżu prawej strony kartki, co prawdopodobnie wskazuje na silne relacje z ojcem bądź innymi ważnymi dla dziecka osobami. Wyraża także potrzebę kontaktu interpersonalnych ze światem zewnętrznym (Chermet-Carroy 1999, s. 32). Odwrotnie zaś należy interpretować umieszczenie rysunku na lewym brzegu kartki. W ten sposób przedstawia siebie dziecko introwertyczne, „uczepione maminej spódnicy”, które jest nieśmiałe, ma potrzebę wycofywania się, zamyka się we własnym świecie, doświadcza trudności w nawiązywaniu kontaktów społecznych oraz w przystosowaniu się do nowej sytuacji (Chermet-Carroy 1999, s. 32; Rodriguez 2011, s. 44, 51). Co ciekawe, w badanej grupie tylko jedynacy umieścili siebie w pobliżu lewej strony kartki.

$\mathrm{W}$ interpretacji prac plastycznych należy również wziąć pod uwagę kolorystykę, która ukazuje wewnętrzny, emocjonalny świat dziecka. Bogata gama kolorów 
oznacza większy wachlarz przeżywanych przez dziecko emocji w danym czasie, z kolei rysunki mało barwne sygnalizują skłonności lękowe bądź zahamowania emocjonalne. Jednak do tego wskaźnika należy podchodzić bardzo ostrożnie i traktować symbole kolorów raczej orientacyjne niż stwierdzająco (Majkut 2014/2015, s. 27). Zdecydowana większość badanych jedynaków i dzieci mających rodzeństwo wykonała rysunki mało barwne, o ograniczonej gamie kolorów. Dane na ten temat zawierają tabele 9 i 10.

Tabela 9. Kolorystyka dominująca na rysunku

\begin{tabular}{|l|c|c|c|c|}
\hline \multirow{2}{*}{ Kolorystyka } & \multicolumn{2}{|c|}{ Jedynacy } & \multicolumn{2}{c|}{ Niejedynacy } \\
\cline { 2 - 5 } & $\mathrm{N}=30$ & $\%$ & $\mathrm{~L}$ & $\%$ \\
\cline { 2 - 5 } & $\mathrm{L}$ & 27 & 11 & 37 \\
\hline Różnobarwna & 8 & 73 & 19 & 63 \\
\hline Mało barwna & 22 & & \multicolumn{2}{c|}{ N } \\
\hline
\end{tabular}

Źródło: opracowanie własne.

Tabela 10. Barwy dominujące na rysunku

\begin{tabular}{|c|c|c|c|c|}
\hline \multirow{2}{*}{ Dominujące kolory } & \multicolumn{2}{|c|}{$\begin{array}{l}\text { Jedynacy } \\
\mathrm{N}=30\end{array}$} & \multicolumn{2}{|c|}{$\begin{array}{c}\text { Niejedynacy } \\
\mathrm{N}=30\end{array}$} \\
\hline & $\mathrm{L}$ & $\%$ & $\mathrm{~L}$ & $\%$ \\
\hline Czerwony & 2 & 7 & 2 & 7 \\
\hline Brązowy & 1 & 3 & 5 & 17 \\
\hline Żółty & 0 & 0 & 1 & 3 \\
\hline Pomarańczowy & 7 & 23 & 9 & 30 \\
\hline Niebieski & 6 & 20 & 1 & 3 \\
\hline Fioletowy & 2 & 7 & 0 & 0 \\
\hline Zielony & 3 & 10 & 5 & 17 \\
\hline Różowy & 2 & 7 & 0 & 0 \\
\hline Czarny & 4 & 13 & 3 & 10 \\
\hline Brak & 3 & 10 & 4 & 13 \\
\hline
\end{tabular}

Źródło: opracowanie własne.

W analizowanych pracach jedynaków dominującymi kolorami były pomarańczowy i niebieski. Dzieci wychowujące się z rodzeństwem preferowały fiolet, pomarańcz i brąz. Przewaga koloru pomarańczowego oznacza żywotność, radość, optymizm, dynamizm oraz jest przejawem chęci zwrócenia na siebie uwagi. Barwa niebieska może być związana z wrażliwością, introwertyzmem, nieśmiałością czy podatnością na bodźce. Kolor fioletowy wyraża połączenie przeciwieństw (bierności i aktywności) oraz pragnienie czegoś innego, w niektórych przypadkach świadczy 
o lęku i niepokoju. Natomiast barwa brązowa wskazuje na pragnienie bezpieczeństwa (Chermet-Carroy 1999, s. 25-27).

Analizując znaczenie barw w rysunku dziecka, należy wziąć również pod uwagę inne wskaźniki, tj. dynamikę nacisku na papier oraz staranność (tabela 11).

Tabela 11. Dynamika nacisku na papier i staranność

\begin{tabular}{|c|c|c|c|c|}
\hline \multirow{2}{*}{$\begin{array}{c}\text { Dynamika nacisku na papier } \\
\text { i staranność }\end{array}$} & \multicolumn{2}{|c|}{$\begin{array}{l}\text { Jedynacy } \\
\mathrm{N}=30\end{array}$} & \multicolumn{2}{|c|}{$\begin{array}{c}\text { Niejedynacy } \\
\mathrm{N}=30\end{array}$} \\
\hline & $\mathrm{L}$ & $\%$ & $\mathrm{~L}$ & $\%$ \\
\hline Duża siła nacisku & 6 & 20 & 9 & 30 \\
\hline Mała siła nacisku & 8 & 27 & 2 & 7 \\
\hline Średnia siła nacisku & 16 & 53 & 19 & 63 \\
\hline Zarysowanie wcześniej stworzonego rysunku & 1 & 3 & 0 & 0 \\
\hline Mała staranność & 20 & 67 & 22 & 73 \\
\hline Duża staranność & 10 & 33 & 8 & 27 \\
\hline
\end{tabular}

Źródło: opracowanie własne.

Dzieci, niezależnie od tego, czy mają rodzeństwo, preferowały kreskę rysowaną ze średnią siłą nacisku na papier, co wskazuje na ich prawidłowy rozwój psychofizyczny. Jednakże przeważali tu niejedynacy, którzy z kolei wykonali mniej rysunków kreską słabą (7\%) w porównaniu do jedynaków (27\%). Mogą one świadczyć o niepewności, lękliwości, delikatności oraz zachowaniach nerwicowych autorów. Więcej prac o dużej dynamice zauważono wśród dzieci niemających rodzeństwa (30\%). Mocną i wyraźną kreskę preferował co piąty jedynak.

Rysunki jedynaków (67\%) i dzieci z rodzin większych (73\%) charakteryzował niewielki stopień dokładności przejawiający się w ukazywaniu niepełnych i statycznych postaci oraz $\mathrm{w}$ rysowaniu poszczególnych elementów $\mathrm{w}$ formie pojedynczych kresek.

Warto również zaznaczyć, iż w grupie jedynaków znalazła się jedna praca z zamazanym wcześniejszym rysunkiem. Świadczyć to może o niepewności autora, wycofaniu i lęku.

W badanych dziełach dzieci zauważono liczne treści będące wskaźnikami niepokoju i lęku (tabela 12) oraz agresji (tabela 13).

W wielu pracach zauważono duże niezapełnione przestrzenie oraz brak ruchu. Niewykorzystane tło spełnia funkcję komunikacyjną lub akomunikacyjną. Zdaniem Małgorzaty Karczmarzyk może oznaczać, że dziecko „chowa się gdzieś w środku własnych problemów i nieuświadomionych emocji” (Karczmarzyk 2008, s. 40). Puste tło wskazuje na lęk i poczucie pustki. Więcej takich prac było w grupie jedynaków. 
Tabela 12. Wskaźniki lęku ujęte w rysunkach badanych dzieci

\begin{tabular}{|c|c|c|c|c|}
\hline \multirow[t]{2}{*}{ Wskaźniki lęku } & \multicolumn{2}{|c|}{$\begin{array}{c}\text { Jedynacy } \\
\mathrm{N}=30\end{array}$} & \multicolumn{2}{|c|}{$\begin{array}{c}\text { Niejedynacy } \\
\mathrm{N}=30\end{array}$} \\
\hline & $\mathrm{L}$ & $\%$ & $\mathrm{~L}$ & $\%$ \\
\hline Duże niezapełnione przestrzenie & 27 & 90 & 22 & 73 \\
\hline Uboga kolorystyka & 18 & 60 & 14 & 47 \\
\hline Brak ruchu & 30 & 100 & 27 & 90 \\
\hline Słaby nacisk kredki & 8 & 27 & 2 & 7 \\
\hline Postacie pomniejszone & 12 & 40 & 9 & 30 \\
\hline Brak podstawy & 23 & 76 & 17 & 57 \\
\hline Treść rysunku przesunięta w lewo & 8 & 27 & 0 & 0 \\
\hline Brak elementów dodanych & 12 & 40 & 7 & 23 \\
\hline Niepełna postać & 11 & 37 & 19 & 63 \\
\hline Smutny charakter rysunku & 16 & 53 & 9 & 30 \\
\hline
\end{tabular}

Źródło: opracowanie własne na podstawie: Braun-Gałkowska, Steuden (2003, s. 94).

Niepełna postać szczególnie widoczna jest w rysunkach dzieci mających rodzeństwo. Uboga kolorystyka, słaby nacisk kredki, małe postacie, brak podstawy, brak elementów dodanych (słońca, rośliny, zwierząt) - to cechy świadczące o podwyższonym poziomie stresu i lęku; występują częściej u jedynaków. Tylko w ich pracach zauważono też przesunięcie rysunku w lewo.

Tabela 13. Wskaźniki agresji ujęte w rysunkach badanych jedynaków i niejedynaków

\begin{tabular}{|c|c|c|c|c|}
\hline \multirow[t]{2}{*}{ Wskaźniki agresji } & \multicolumn{2}{|c|}{$\begin{array}{c}\text { Jedynacy } \\
\mathrm{N}=30\end{array}$} & \multicolumn{2}{|c|}{$\begin{array}{c}\text { Niejedynacy } \\
\mathrm{N}=30\end{array}$} \\
\hline & $\mathrm{L}$ & $\%$ & $\mathrm{~L}$ & $\%$ \\
\hline Dominacja koloru czerwonego i czarnego & 3 & 10 & 1 & 3 \\
\hline Silny nacisk kredki & 6 & 20 & 9 & 30 \\
\hline Brak ruchu & 30 & 100 & 27 & 90 \\
\hline Duże postacie & 6 & 20 & 5 & 17 \\
\hline Dodane elementy wskazujące na agresję & 1 & 3 & 0 & 0 \\
\hline
\end{tabular}

Źródło: opracowanie własne.

Na szczególną uwagę zasługuje praca chłopca z grupy jedynaków. Na jego rysunku pojawia się aż pięć wskaźników agresji (tabela 13). Przewaga kolorów czarnego i czerwonego prawdopodobnie wiąże się z gniewem, bezsilnością i beznadzieją, negacją, śmiercią. Silny nacisk kredki wskazuje na nadpobudliwość ruchową, a duże postacie są oznaką ekspansywności. Brak ruchu i dynamiki oznacza poczucie braku bezpieczeństwa i swobody. W pracy chłopca zostały zawarte symbol śmierci (czaszka) oraz „narzędzie do zabijania”. Należy nadmienić, iż dziecko pochodzi z rodziny zrekonstruowanej i wychowuje się w dwóch domach, na zmianę u matki i ojca. 
Mały człowiek nieświadomie przeniósł swoją sytuację problemową na papier. Jest to mowa graficzna chłopca, który zwraca się do dorosłych słowami: „pomóżcie mi!”.

\section{PODSUMOWANIE}

Zgromadzone rysunki wyrażają stan emocjonalny dzieci w wieku wczesnoszkolnym. W trakcie analizy zauważono podobieństwa i różnice w postrzeganiu siebie przez jedynaków i dzieci mające rodzeństwo.

Na podstawie niektórych prac można wstępnie wnioskować, iż część autorów ma zaniżone poczucie własnej wartości. U niektórych z nich dostrzeżono symptomy niepokoju o różnym nasileniu. Przykładowo: ponad połowa jedynaków i dzieci mających rodzeństwo narysowała swoje nogi mało stabilnie, bez podstawy. Wydaje się, iż dzieci te mogą mierzyć się z jakimiś trudnościami, które zaburzają ich wewnętrzną harmonię. Większość prac charakteryzuje się ubogą kolorystyką i małą starannością rysunku (postacie niepełne, „zamazywanki”, brak elementów dodanych), co może świadczyć o napięciach psychicznych. Cechą wspólną prac jedynaków i niejedynaków było też puste tło, które może sygnalizować poczucie wewnętrznej pustki połączonej z bezsilnością wobec tego, co dziecko otacza.

Wytwory plastyczne jedynaków różniły się pewnymi elementami od rysunków dzieci mających rodzeństwo. Prace jedynaków w większym zakresie niż rysunki dzieci $\mathrm{z}$ rodzin większych ujawniały wskaźniki niepokoju. W analizowanych obrazach dzieci wychowujących się bez rodzeństwa charakterystyczne były: umiejscowienie siebie na lewym brzegu kartki, brak ruchu, rysowanie małych postaci, słabe naciskanie kredki na papier. Te elementy mogą wskazywać na introwertyczną naturę, nieśmiałość, lękliwość i delikatność. Nadwrażliwość jedynaków prawdopodobnie wynika z sytuacji, w jakiej się znajdują. Jako jedyne dzieci $\mathrm{w}$ rodzinie często przebywają $\mathrm{z}$ osobami dorosłymi, co utrudnia ich procesy adaptacyjne $\mathrm{w}$ grupie rówieśniczej. Zapewne $\mathrm{z}$ tego powodu doświadczają też samotności i wyobcowania (powstały dwa rysunki przedstawiające autorów wraz z rówieśnikami). Równocześnie nadopiekuńczość, silna miłość i zbyt troskliwa opieka mogą prowadzić do lęku przed utratą rodziców oraz do formowania się postawy zależności między dzieckiem a rodzicem - najczęściej matką. Ponadto tylko w grupie badanych jedynaków znalazły się trzy rysunki ukazujące dziecko $\mathrm{w}$ roli bohatera $\mathrm{z}$ bajki i gry komputerowej, co prawdopodobnie oznacza $\mathrm{z}$ jednej strony identyfikowanie się z ulubioną postacią, a z drugiej wybujałą wyobraźnię i dążenie do idealnego wyglądu.

Dzieci mające rodzeństwo realnie przedstawiły siebie na rysunku, prawie wszystkie umieściły postać w centrum kartki. Może to świadczyć o poczuciu bezpieczeń- 
stwa i prawidłowych zdolnościach adaptacyjnych. W grupie niejedynaków więcej było prac wykonanych na poziomie poniżej wieku życia.

Badania pokazały, że dzieci w wieku 6-7 lat różnie obrazują własne „ja” pod względem fizycznym i psychicznym. To, jak siebie widzą, jest odzwierciedleniem tego, jak inni o nich mówią i za kogo je uważają. Świat najbliższych stanowi jedyny świat dany dziecku z narzuconymi przez dorosłych sposobami życia. Tylko bezwarunkowa miłość, szacunek i akceptacja rodziców pozytywnie modelują poczucie własnej wartości. Należy podkreślić, że we wczesnym dzieciństwie bardzo intensywnie konstruują się samoocena i wiara we własne możliwości. Jest to fundament, z którego czerpie się siły przez całe życie.

Przeprowadzone badania nie wyczerpują całkowicie podjętego tematu. Warto je pogłębić przy użyciu stosownych kwestionariuszy. Wnioski wyciągnięte z analizy rysunków mogą pomóc w odpowiedzeniu na potrzeby dzieci.

\section{LITERATURA}

Adamczykowa Z., 2008, Literatura „czwarta” - w kregu zagadnień teoretycznych. W: K. Heska- Kwaśniewicz (red.), Literatura dla dzieci i młodzieży (po roku 1980). Katowice, Wydawnictwo UŚ.

Braun-Gałkowska M., Steuden S., 2003, Projekcja niepokoju w rysunku. W: M. Łaguna, B. Lachowska (red.), Rysunek projekcyjny jako metoda badań psychologicznych. Lublin, Wydawnictwo KUL.

Brzezińska A., 1973, Struktura własnej osoby i jej wpływ na zachowanie. „Kwartalnik Pedagogiczny", nr 3, 87-97.

Goffman E., 2006, Rytuał interakcyjny. Tłum. A. Szulżycka. Warszawa, Wydawnictwo Naukowe PWN.

Chermet-Carroy S., 2005, Zrozum rysunki dziecka, czyli jak interpretować rysunki małych dzieci. Kolory, kształty, postacie. Tłum. J. Kluza. Łódź, Wydawnictwo Ravi.

Filipczuk H., 1976, Kłopoty z jedynakami. Warszawa, Wydawnictwo Nasza Księgarnia.

Karczmarzyk M., 2008, „Puste znaczące rysunku” jako różne reprezentacje graficzne tła w twórczości plastycznej dzieci i dojrzałych artystów. W: E. Szatan, D. Bronk (red.), Gdyby Einstein współcześnie chodził do szkoły... Dziecko i twórczość w pedagogice wczesnoszkolnej. Gdańsk, Wydawnictwo UG.

Kalbarczyk A., 2007, Najważniejsze lata, czyli jak rozumieć rysunki małych dzieci. Rozwój osobowości dziecka w wieku od 2 do 6 lat na postawie jego rysunków. Kraków, Oficyna Wydawnicza Impuls. 
Knedler A., 2011, Samoocena u dzieci. „ArteTerapia”, nr 1, 28-29.

Kostrubiec B., Mirucka B., 2004, Rysunek projekcyjny w badaniach obrazu siebie. Lublin, Wydawnictwo KUL.

Kulas H., 1986, Samoocena młodzieży. Warszawa, WSiP.

Kumpel M., 2015, Jedynak. Warszawa, Wydawnictwo Lekarskie PZWL.

Lowenfeld V., Brittain W.L., 1997, Twórczość a rozwój umysłowy dziecka. Warszawa, Wydawnictwo Naukowe PWN.

Majkut M., 2014/2015, Twórczość plastyczna dziecka w wieku wczesnoszkolnym. „Nauczanie Początkowe”, nr 4, 20-28.

Oster G.D., Gould P., 2004, Rysunek w psychoterapii. Gdańsk, GWP.

Popek S., 2001, Barwy i psychika. Percepcja. Ekspresja. Projekcja. Lublin, Wydawnictwo UMCS.

Popek S., 1978, Analiza psychologiczna twórczości plastycznej dzieci i młodzieży. Warszawa, WSiP.

Rodriguez N., 2013, Co nam mówią rysunki dzieci? Kielce, Wydawnictwo Jedność. Schaffer H.R., 2005, Psychologia dziecka. Warszawa, Wydawnictwo Naukowe PWN. Turowska L., 1987, Środowisko rodzinne jedynaka a jego przystosowanie szkolne. Wrocław, Zakład Narodowy im. Ossolińskich.

Tyszkowa M., 1985, Badania nad uspołecznieniem i osobnością dzieci jedynych i mających rodzeństwo. W: M. Tyszkowa (red.), Rozwój dziecka w rodzinie i poza nią. Poznań Wydawnictwo UAM.

\section{SELF-PERCEPTION OF ONLY CHILDREN AND CHILDREN WITH SIBLINGS}

Abstract: The article presents the results of the author's personal research concerning self-image issues in the drawings of only children and children with siblings. The research conducted provides significant information on the children's personality, self-assessment, self-esteem and creative activity in early education. It also enables to answer questions regarding the differences in the self-perception of only and non-only children.

Keywords: self-image, self-assessment, self-esteem, an only child, a projective drawing 